\title{
30. ORGANIC FACIES AND HYDROCARBON POTENTIAL IN THE GULF OF CALIFORNIA ${ }^{1}$
}

\author{
Deborah Gilbert and Colin P. Summerhayes, Exxon Production Research Co., Houston, Texas
}

\begin{abstract}
The sediments from the Gulf of California are potentially good sources for oil and gas. They are rich in organic carbon (av. $=1.9 \%$ ). Sediments from the margins of the Gulf are rich in oil-prone marine-amorphous organic matter. Sediments from Guaymas Basin contain the same material plus abundant subordinate amounts of gas-prone terrestrially derived organic matter. The enrichment of all of these sediments in marine-amorphous components reflects deposition in a highly productive and oxygen-poor water mass. The sediments are thermally immature, except for those altered by hydrothermal activity or by the intrusion of sills. These sediments are extensively cooked and may have lost their potential for hydrocarbon generation.
\end{abstract}

\section{INTRODUCTION}

As part of our continuing organic geochemical studies of sediments recovered by the Deep Sea Drilling Project, we have analyzed the types, amounts, and thermal alteration indices (TAIs) of organic matter in samples collected from the Gulf of California on Leg 64 (Table 1). All of the samples were frozen; some were core samples and others were canned on site (Table 1). We analyzed selected samples for extractable $\mathrm{C}_{15+}$ components (Tables 2; 3; Figure 1) and canned samples for gases and organic matter (Table 4).

The Gulf of California is a newly forming ocean basin that began spreading about $4 \mathrm{Ma}$. The sediments in the gulf may be recent analogs of those, e.g., in the North and South Atlantic, formed early in the history of other passive margins.

Our objectives were (1) to determine the organic facies of the different parts of the gulf and relate the facies to the predominant sedimentary processes; (2) to measure the effects on this organic matter of the high heat flow and intrusion of sills typical of the Gulf; and (3) to estimate the probable hydrocarbon potential of the sediments.

The sites fall into three groups. One group (Sites 474; $475 ; 476$ ) is in the Baja California continental margin. It is the youthful stage of an evolving, passive margin. A second group (Sites $477 ; 478 ; 481$ ) is in the Guaymas Basin, where spreading causes sills to intrude fresh sediments. The third group (Sites $479 ; 480$ ) is in the Mexican continental margin, where varved, organically enriched sediments are being deposited within the oxygen minimum (Calvert, 1964; 1966).

\section{RESULTS}

\section{Type and Amount of Organic Matter}

Baja California Passive Margin (Holes 474 at $3023 \mathrm{~m} ; \mathbf{4 7 5}$ at $2631 \mathrm{~m}$; and 476 at $2400 \mathrm{~m}$ )

On average, these sediments contain $1.8 \%$ total organic carbon (TOC), most of which (av. $=85 \%$ ) is

\footnotetext{
${ }^{1}$ Curray, J. R., Moore, D. C., et al., Init. Repts. DSDP, 64: Washington (U.S. Govt. Printing Office).
}

amorphous organic matter (Table 1). Organic richness and organic facies (the assemblage of different types of organic matter) vary only slightly through the lower Pliocene into the Quaternary (Table 1), but the shallowest sample (474-2-3) has the most TOC (3.67\%).

Changes in sedimentary processes do not seem to have affected organic facies. The turbidites and slump deposits are very similar. Their TOCs average $1.73 \%$, and their organic facies is $80 \%$ amorphous and $12.5 \%$ terrestrial (Table 1). This is not much different from the more slowly deposited, diatomaceous, hemipelagic oozes. Excluding the rich surface sample from Hole 474 , the ooze averages $1.53 \%$ TOC, and their organic facies are $87 \%$ amorphous and $6.7 \%$ terrestrial (Table 1). The sediments are similar because the turbidites and slumped material comprise diatomaceous ooze derived from upslope. Material from upslope has a slightly larger terrestrial component than the in situ ooze. From the basin setting, the abundance of diatomaceous material, the presence of subordinate structured marine organic matter (Table 1), and the abundant bitumen extract (Table 2), we infer that much of the amorphous material is marine derived and oil prone.

\section{Guaymas Basin (Holes 477 at 2003 m; 478 at $1889 \mathrm{~m}$; 481 at $1998 \mathrm{~m}$ )}

Most of the Guaymas Basin samples are turbidites. They contain much more terrestrial and less marine or amorphous organic matter than the Baja margin sites (Table 1). Structured terrestrial material averages $22 \%$; pollen, spores, and biodegraded terrestrial material average $5 \%$, coaly material (mostly oxidized wood fragments) averages $14 \%$, amorphous material averages $46 \%$, and structured marine material averages $12 \%$. Some samples contain only terrigenous organic matter (e.g., 477-16-5), whereas others are exclusively marine (e.g., 481-2-2):We assume that most of the amorphous material is marine derived; this means that about $40 \%$ of the organic matter in the basin is derived from higher land plants.

Our assumption is supported by the abundance of extractable bitumen (Table 2) and by the appearance of the gas chromatogram of the $\mathrm{C}_{15+}$ saturated hydrocarbon fraction of Sample 481-26-5 (Fig. 1). The chro- 
Table 1. Age, lithology, sedimentation rate, organic carbon content, type of organic matter, and thermal alteration indices (TAI) of DSDP samples from the Gulf of California.

\begin{tabular}{|c|c|c|c|c|c|c|c|c|c|c|c|c|c|}
\hline \multirow{2}{*}{$\begin{array}{l}\text { Sill } \\
\text { Depth } \\
\text { (m) }\end{array}$} & \multirow{2}{*}{$\begin{array}{c}\text { Sample } \\
\text { (interval in } \mathrm{cm} \text { ) }\end{array}$} & \multirow{2}{*}{$\begin{array}{l}\text { Drill } \\
\text { Depth } \\
\text { (m) }\end{array}$} & \multirow{2}{*}{$\begin{array}{c}\text { Organic } \\
\text { Carbon } \\
\text { Content } \\
(\%)\end{array}$} & \multicolumn{6}{|c|}{ Type of Organic Matter } & \multirow[b]{2}{*}{ TAI } & \multirow[b]{2}{*}{ Agej } & \multirow{2}{*}{$\begin{array}{c}\text { Sedimentation } \\
\text { Rate } \\
\text { (m/m.y.) }\end{array}$} & \multirow[b]{2}{*}{ Lithologyj } \\
\hline & & & & STa & PS $b$ & $\mathrm{Cc}^{\mathrm{c}}$ & $\mathrm{BT}$ d & $\mathrm{AM}^{\mathrm{e}}$ & $S M^{f}$ & & & & \\
\hline \multicolumn{14}{|c|}{ Baja California Continental Margin } \\
\hline & $474-2-3,135-140$ & 6.3 & 3.67 & & & & & 99 & & 1 & Q8 & 80 & Hemipelagic diatomaceous mud and marl \\
\hline & $474-6-5,15-20$ & 46.2 & 1.22 & 5 & & 5 & & 90 & & 1 & Q & Slump & Debris flow (diatomaceous mud and marl) \\
\hline & $474 \mathrm{~A}-7-2,115-121$ & 223.2 & 1.12 & 10 & & 5 & & 75 & 10 & 1 & Q & 240 & \\
\hline & $474 \mathrm{~A}-24-2,140-150^{k}$ & 375.5 & 1.23 & 10 & 5 & 10 & & 65 & 10 & $1+$ & $Q_{b}$ & 240 & Mud turbidite \\
\hline 521 & $474 \mathrm{~A}-32-2,130-134$ & 451.2 & 1.72 & 5 & & & & 95 & & $1+$ & LPh & $74)$ & \\
\hline 563 & $474 A-41-3,135-150$ & 538.3 & 0.80 & 5 & & 5 & & 90 & & 2 & $E P^{i}$ & 40 & Clayey silt \\
\hline & $475-2-2,120-126$ & 8.7 & 2.47 & 5 & & 5 & & 85 & 5 & 2 & Q & 80 & Hemipelagic diatomaceous mud \\
\hline & $475-12-4,120-130$ & 106.8 & 2.26 & & & & & 90 & 10 & $1+$ & LP & 48 & Hemipelagic mud \\
\hline & $475-16-2,130-135$ & 141.8 & 2.96 & 5 & & 5 & & 80 & 10 & 1 & EP & 38 & Diatomaceous mud turbidite \\
\hline & $476-3-4,127-133$ & 24.3 & 1.24 & 10 & & & & 70 & 20 & 1 & Q & 93 & Hemipelagic diatomaceous and nannofossil ooze \\
\hline & $476-11-4,116-121$ & 100.2 & 0.91 & 5 & & 5 & & 90 & & $2-$ & LP & 42 & Hemipelagic mud \\
\hline & $476-19-1,120-135$ & 171.7 & 2.13 & 5 & & 5 & & 80 & 10 & $1+$ & EP & 37 & Turbidite \\
\hline \multicolumn{14}{|c|}{ Guaymas Basin } \\
\hline 58 & $477-5-1,120-129$ & 30.8 & 2.55 & 5 & & 5 & & 65 & 25 & $1+$ & Q & 1000 & Diatomaceous ooze and turbidite \\
\hline & $477-16-5,58-62$ & 120.7 & 0.83 & 55 & 5 & 35 & & 5 & & 3 & Q & $1000\}$ & Hydrothermally altered terrigenous turbidites \\
\hline & $477-20-2$, topk & 154.5 & 1.08 & 50 & & 25 & & 25 & & $2+$ & $\mathrm{Q}$ & $1000\}$ & \\
\hline & $478-6-3,137-143$ & 45.9 & 1.55 & 20 & 10 & 10 & 10 & 50 & & $1+$ & $\mathrm{Q}$ & 1000 & \\
\hline & $478-9-3,130-135$ & 74.2 & 2.25 & 10 & & 5 & & 85 & & $1+$ & $\mathrm{Q}$ & 1000 & Muddy diatomaceous ooze with some \\
\hline & $478-11-3,0-5^{k}$ & 92.0 & 0.68 & 25 & 5 & 15 & & 35 & 20 & $2-$ & $\mathrm{Q}$ & 1000 & $\begin{array}{l}\text { Muddy diatomaceous ooze with some } \\
\text { sandy turbidites }\end{array}$ \\
\hline & $478-16-4,120-125$ & 141.3 & 1.31 & 40 & 5 & 30 & 5 & 10 & 10 & $1+$ & Q & 1000 & \\
\hline & $478-19-1,0-10^{k}$ & 159.5 & 1.33 & 30 & 5 & 15 & & 35 & 15 & $2-$ & Q & $1000)$ & \\
\hline 220 & $478-20-4,108-123$ & 170.3 & 1.19 & 15 & 10 & 10 & 5 & 55 & 5 & $1+$ & Q & 1000 & \\
\hline 253 & $478-28-2,131-137$ & 247.3 & 1.54 & 5 & & 5 & & 85 & 5 & $1+$ & $\mathrm{Q}$ & 1000 & Diatomaceous mud \\
\hline 342 & $478-35-5,116-120$ & 307.0 & 0.45 & 15 & 10 & 35 & 5 & 30 & 5 & $2+$ & Q & 1000 & Diatomaceous mud (some laminated) \\
\hline & $481-2-2,125-130$ & 7.5 & 3.64 & & & & & 95 & 5 & $2-$ & Q & $1000\}$ & Muddy diatomaceous ooze/turbidite \\
\hline & $481-11-1,140-145$ & 48.9 & 1.76 & 20 & & 5 & & 65 & 5 & $2-$ & Q & $1000\}$ & \\
\hline & $481 \mathrm{~A}-6-5,150-155^{\mathrm{k}}$ & 97.0 & 1.68 & 10 & & 5 & & 65 & 20 & $1+$ & $\mathrm{Q}$ & 1000 & Turbidite \\
\hline 168 & $481 \mathrm{~A}-12-2,120-126$ & 149.2 & 0.96 & 40 & & 20 & 10 & 20 & 10 & $2-$ & Q & 10001 & ค \\
\hline & $48 \mathrm{IA}-22-1,0-5 \mathrm{k}$ & 242.0 & 1.88 & 10 & & 10 & & 60 & 20 & $1+$ & Q & 1000 & \\
\hline & $481 \mathrm{~A}-26-5,120-135$ & 286.7 & 1.36 & 40 & & 10 & 10 & 20 & 20 & $2-$ & Q & $1000\}$ & Laminated diatomaceous mud and mud flows \\
\hline 328 & $481 \mathrm{~A}-30-5,125-133$ & 325.4 & 2.00 & 10 & & 5 & & 30 & 55 & 2 & Q & $1000)$ & \\
\hline \multicolumn{14}{|c|}{ Varved Diatomite } \\
\hline & $479-3-2,105-108$ & 15.1 & 3.05 & & & 5 & & 85 & 10 & $2-$ & Q & $380)$ & \\
\hline & $479-9-2,130-135$ & 72.3 & 2.25 & & 5 & 10 & & 85 & 10 & $1+$ & Q & 380 & \\
\hline & $479-12-1,15-20^{k}$ & 98.2 & 2.29 & 10 & & 5 & & 75 & 10 & $1+$ & Q & 380 & Varved hemipelagic diatomaceous ooze \\
\hline & $479-15-5,129-140$ & 133.8 & 2.96 & 5 & & & & 95 & & $1+$ & Q & 380 & (sparse carbonate) \\
\hline & 479-22-7, bottomk & 202.5 & 2.53 & 10 & & & & 70 & 20 & $1+$ & Q & 380 & \\
\hline & $479-27-4,120-126$ & 246.2 & 2.11 & 5 & 5 & 5 & 5 & 75 & 5 & 2- & Q & 380 & \\
\hline & $479-34-5,125-140$ & 314.3 & 3.09 & & & 5 & & 95 & & $2-$ & $\mathrm{Q}$ & 380 & Same; more calcareous \\
\hline & $479-39-4,130-135$ & 360.3 & 3.81 & & & 5 & & 90 & 5 & 2- & Q & $380\}$ & Diatomaceous claystone with \\
\hline & $479-47-4,134-137$ & 436.4 & 1.05 & & & 10 & & 75 & 15 & $2-$ & Q & $380\}$ & calcareous mudstone \\
\hline & $480-20-3,62-72$ & 49.5 & 2.47 & & & & & 95 & 5 & $2-$ & Q & $380\}$ & \\
\hline & $480-31-2,150-155^{k}$ & 148.8 & 2.39 & 10 & 5 & & & 65 & 20 & $1+$ & Q & $380\}$ & Varved diatomaceous ooze \\
\hline
\end{tabular}

\footnotetext{
a Structured terrestrial.

b Pollen and spores.

c Charcoal.

d Biodegraded terrestrial.

e Amorphous.

f Structured marine types of organic matter (see Masran and Pocock, 1979).

8 Quaternary.

h Late Pliocene.

Early Pliocene.

Shipboard data.

k Canned sample (others $=$ core sample).
}

matogram has a rather unusual appearance, representing a mixture of marine components (the abundant naphthenes and the $\mathrm{nC}_{18}$ and $\mathrm{nC}_{19}$ paraffins) and terrestrial components (the longer chain paraffins, such as $\mathrm{nC}_{24}-\mathrm{nC}_{27}$, where there is an odd carbon preference). Superimposed on the chromatogram are $\mathrm{C}_{21^{+}}$steranes and $5 \alpha$-cholestane. The low isoprenoid content suggests that zooplankton is more abundant than phytoplankton (G. G. L. Rinaldi, personal communication).

These sediments are about as rich as those of the Baja margin, with an average TOC of $1.6 \%$. As on the Baja margin, the shallowest sample has an anomalously high TOC $(3.64 \%$ at Hole 481$)$. The variability in both TOC and organic facies downhole indicates multiple sources for these Quaternary sediments. One major source must be the continental slope, where marine organic matter accumulates in diatomaceous ooze. The major source of higher land plant material is probably the Yaqui River, which discharges into the central Gulf.

\section{Varved Diatomite Sites (Holes 479 at 747; 480 at $655 \mathrm{~m}$ )}

These Quaternary sediments are typically laminated. Some laminae are rich in diatoms; others are rich in clay, suggesting an interplay between marine and terrestrial input. The marine component dominates the organic fraction, which is about $80 \%$ amorphous and $10 \%$ structured marine (Table 1). Locally, the terrigenous input becomes more obvious, as in Sample 479-27-4 
Table 2. Extractable $\mathrm{C}_{15^{*}}$ bitumens $=$ (hydrocarbons and nonhydrocarbons)

\begin{tabular}{cccc}
\hline Sample & $\begin{array}{c}\text { Drill } \\
\text { Depth } \\
(\mathrm{m})\end{array}$ & $\begin{array}{c}\text { TOCa } \\
(\%)\end{array}$ & $\begin{array}{c}\text { Total } \\
\text { Extract } \\
(\mathrm{ppm})\end{array}$ \\
\hline \multicolumn{4}{c}{ Baja California Continental Margin } \\
474A-32-2 & $\begin{array}{l}\text { 451.2 } \\
\text { 475-12-4 }\end{array}$ & 1.72 & 896 \\
Guaymas Basin & 2.26 & 1806 \\
481A-26-5 & & \\
Varved Diatomite & 1.36 & 865 \\
479-9-2 & & \\
479-15-5 & 72.3 & 2.25 & 3584 \\
\hline
\end{tabular}

a Organic carbon content.

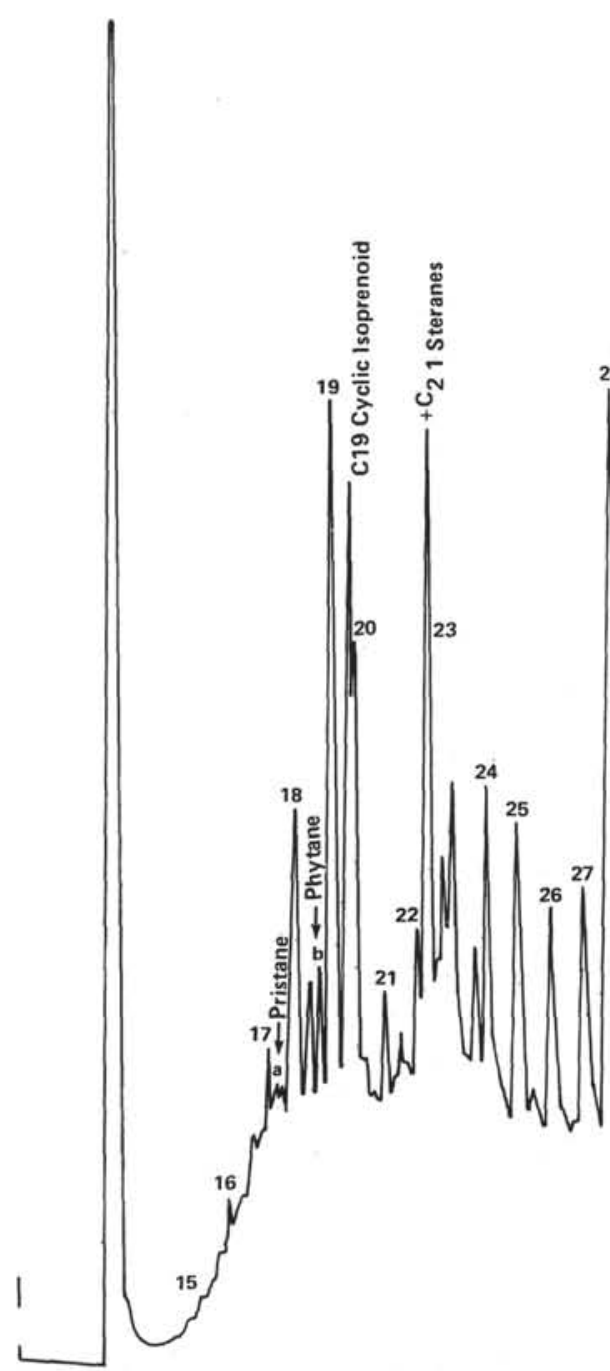

Figure 1. $\mathrm{C}_{15}$ distribution (481A-26-5, $\left.286.7 \mathrm{~m}\right)$.

where $20 \%$ of the organic matter has a terrestrial source. Had we been able to analyze individual laminae, we probably would have found more terrestrial organic matter in the clay layers than in the diatomaceous laminae. The terrestrial content at these depths is clearly much less than it is downslope in the Guaymas Basin.

The varved diatomites, the sediments richest in organic carbon (av. $=2.5 \%$ TOC), occur in the oxygen minimum zone beneath highly productive surface waters. But compared to typical, rich source rocks from oil-producing areas (TOC $\geq 5 \%$ ), these sediments are lower in organic carbon. The high sedimentation rate $(380 \mathrm{~m} / \mathrm{m}$.y. $)$ in this area effectively dilutes this concentration of organic carbon (Weeks, 1952). The abundant bitumen extract confirms the marine oil-prone character of these sediments (Table 2).

\section{Thermal Alteration Indices}

The Gulf is an area of high heat flows where sediments are being intruded by sills and altered hydrothermally near the spreading center (Einsele et al., 1980). The sites topographically and geographically farthest from the spreading center (Holes 476 and 479) have the lowest heat flow $\left(2.4\right.$ heat flow units $\left[\mathrm{HFU}=10^{-6} \mathrm{cal}\right.$ $\left.\left.\mathrm{cm}^{-2} \mathrm{~s}^{-1}\right]\right)$. Most of the deeper sites closer to the spreading center have HFUs of 2.7-4.0, except Hole 477, which has an HFU of 20 (Einsele et al., 1980). The deepwater sites are intruded by sills (Holes 474, 477, 478; 481) (Einsele et al., 1980), and one (Hole 477) is hydrothermally altered at drill depths greater than 100 meters (Table 1).

Where there are no intrusions (Holes 475, 476, 479; 480 ), the regional heat flow may be the sole cause of the maturation of organic matter. Rapid maturation is indicated by the downhole increase in TAI from $1+$ to $2-$ in Hole 479 (Table 1). The other nonintruded sections were not sampled to this depth but most, e.g., the shallow section from Hole 479, have TAIs of $1+$.

Sills and hydrothermal alteration have an additive effect, causing TAIs to reach 2 (Holes 474; 481), $2+$ (Hole 478), and even 3 (Hole 477) (Table 1). According to the shipboard data, the effect of sills is confined to within a few meters of the intrusion. Many sediments between the sills in the intruded sections have TAIs as low as $1+$ (e.g., Holes 478; 481) (Table 1).

Sediments with TAIs of $1+$ are thermally immature. Values of 2 - are borderline and probably signify an immature section. Where the TAI is 2 or more, hydrocarbons may have been generated from oil-prone sediments. Where the TAIs reach values of 3 or more, the organic matter has used up most of its potential to generate liquids and approaches the overmature, gas-prone stage. The immaturity of Sample 481-26-5 at 286.7 meters (TAI $=2-$ ) is indicated by a chromatogram (Fig. 1) and by the total hydrocarbon content and saturate/aromatic ratio of the sample (Table 3 ).

\section{Gas Content}

Most of the gas in these samples was methane (Table 4). Of the wet gas fraction $\left(C_{2}-C_{4}\right)$, ethane usually predominates. The $C_{1} /\left(C_{2}+C_{3}\right)$ ratio is relatively high in the nonintruded sections (Holes $479 ; 480$ ), relatively low near the sills in the intruded sections (Holes 474; 477; Sample 481-22-1) and high well above the sills in the intruded sections (Hole 478; Sample 481-6-5) (Table 4). 
Table 3. Composition of $\mathrm{C}_{15^{+}}$extract from Guaymas Basin sample (481A-26-5, $286.7 \mathrm{~m})$.

Bulk percentage composition of $\mathrm{C}_{15^{+}}$extract (hydrocarbons and nonhydrocarbons)

Saturates Aromatics Sulfur $\mathrm{NSOs}^{\mathrm{a}}$ Asphaltenes

$\begin{array}{lllll}1.1 & 6.5 & 3.9 & 33.4 & 55.1\end{array}$

Saturated hydrocarbon analysis (percentage composition from Fig. 1) $n$-Paraffins Isoprenoids Naphthenes

19.6 0.6 79.8

${ }^{a} \mathrm{~N}, \mathrm{~S}, \mathrm{O}$ compounds.

Low ratios $(<50)$ are typical of thermogenic gas, and high ratios $(>1000)$ are typical of biogenic gas (Bernard et al., 1976). This suggests that our samples with low ratios $(<100)$ are mainly thermogenic, and our samples with high ratios (mostly $>300$ ) are mainly biogenicthermogenic mixtures. The ratios for $\mathrm{C}_{2} / \mathrm{C}_{1}$ could be used to show the same thing (as in the shipboard data for this leg), the two ratios being inversely related.

Comparing our data with the shipboard data shows that our $\mathrm{C}_{2} / \mathrm{C}_{1}$ ratios are usually high by an order of magnitude. In spite of the discrepancy, our data confirm the trends in the shipboard data and the conclusions drawn from those data. Evidently, even where the section is rated immature by TAI analysis, some of the gas may be thermogenic. The thermogenic components are probably diffusing upward through the section.

Gas abundances are consistently high (av. $=24,124$ ppm)-twice as high as the gas in sediments from the California margin (Gilbert and Summerhayes, 1980) and four times as high as the gas in sediments from the margin of Japan (Gilbert et al., 1980). We assume that this results from thermogenic gas in the present Gulf of California sediments, the other areas being immature and having exclusively biogenic gas.

\section{Hydrocarbon Potential}

The richness of the bitumen extracts (av. $\mathrm{C}_{15^{+}}$extractable bitumen $=2033 \mathrm{ppm}$ ) confirms the oil-prone diagnosis. The samples analyzed for bitumen are immature.
From their bitumen content, we rate them as very good potential sources for oil. This potential may be realized where these sediments are more deeply buried and more mature. Bitumen correlates broadly with TOC (Table 2), making the varved diatomite sites the most oil-prone sections in the Gulf.

\section{DISCUSSION}

TOCs in the Gulf of California vary from one environment to another and are higher than in most other continental margins. The high values of the varved diatomites $(2.5-3 \%)$ result from deposition within the oxygen minimum, an environment 300-1400 meters deep where organic matter is preserved because of the low oxygen content of the water mass $(<0.5 \mathrm{ml} / \mathrm{l})$ (Calvert, 1964, 1966). Sediments from the oxygen minimum of the California borderland have similar TOCs (av. $=2.1 \%$ in the Quaternary and 3.9\% in the Mio-Pliocene) (Gilbert and Summerhayes, 1980). The deeper samples, from the Baja margin and the Guaymas Basin, have less TOC (av. $=1.5-2 \%$ ) than the varved diatomites but still have twice as much as, for example, the Japan margin (Gilbert et al., 1980). Although TOCs can be increased under oxidizing conditions by increasing the rates of sedimentation (Weeks, 1958), this does not explain the difference between the Japan margin and the Gulf of California. Rates of sedimentation are high in both areas. We believe that the answer lies either in the high biological productivity of the gulf or in the generally low oxygen content of gulf bottom waters. Below the oxygen minimum layer $(<0.5 \mathrm{ml} / \mathrm{l})$, oxygen levels rise only to about $0.7 \mathrm{ml} / 1$ (Calvert, 1966). This is sufficiently low to inhibit the oxidation of organic matter and discourage benthic and bacterial activity, thus inhibiting the decomposition of organic matter in surface sediments.

The anomalously high TOCs of near-surface sediments support the idea that conditions in the gulf below the oxygen minimum approach the ideal for the accumulation and preservation of organic matter. For example, in Holes 474 and 481, our least-buried samples have

Table 4. Gas analyses (ppm vols.).

\begin{tabular}{|c|c|c|c|c|c|c|c|c|c|c|}
\hline $\begin{array}{c}\text { Sample } \\
\text { (interval in } \mathrm{cm} \text { ) }\end{array}$ & $\begin{array}{l}\text { Sub-bottom } \\
\text { Depth } \\
\text { (m) }\end{array}$ & $C_{1}$ & $\mathrm{C}_{2}$ & $\mathrm{C}_{3}$ & $\mathrm{C}_{4}$ & $\begin{array}{l}C_{2} / C_{1} \\
\left(\times 10^{-4}\right)\end{array}$ & $\begin{array}{c}\mathrm{C}_{1} / \\
\left(\mathrm{C}_{2}+\mathrm{C}_{3}\right)\end{array}$ & $\begin{array}{c}\text { Organic } \\
\text { Carbon } \\
\text { Content } \\
(\%)\end{array}$ & $\begin{array}{c}\mathrm{C}_{2} \text { in } \\
\mathrm{C}_{2}-\mathrm{C}_{4} \\
(\%)\end{array}$ & $\begin{array}{c}\mathrm{C}_{3} \text { in } \\
\mathrm{C}_{2}-\mathrm{C}_{4} \\
(\%)\end{array}$ \\
\hline \multicolumn{11}{|c|}{ Baja California Continental Margin } \\
\hline $474 \mathrm{~A}-24-2,140-150$ & 375.5 & 5413 & 46 & 33 & 37 & 84.9 & 69 & 1.23 & 39 & 29 \\
\hline \multicolumn{11}{|l|}{ Guaymas Basin } \\
\hline $\begin{array}{l}477-20-2, \text { top } \\
478-11-3,0-5 \\
478-19-1,0-10 \\
481 \mathrm{~A}-6-5,150-155 \\
481 \mathrm{~B}-22-1,0-5\end{array}$ & $\begin{array}{r}154.5 \\
92.0 \\
159.5 \\
97.0 \\
242.0\end{array}$ & $\begin{array}{l}24,136 \\
28,203 \\
59,389 \\
31,551 \\
11,402\end{array}$ & $\begin{array}{r}286 \\
45 \\
55 \\
93 \\
51\end{array}$ & $\begin{array}{r}10 \\
12 \\
18 \\
7 \\
69\end{array}$ & $\begin{array}{l}2.6 \\
6 \\
20 \\
8 \\
13.3\end{array}$ & $\begin{array}{r}118.0 \\
16.0 \\
9.3 \\
29.5 \\
44.7\end{array}$ & $\begin{array}{r}82 \\
495 \\
813 \\
316 \\
95\end{array}$ & $\begin{array}{l}1.08 \\
0.68 \\
1.33 \\
1.68 \\
1.88\end{array}$ & $\begin{array}{l}96 \\
72 \\
60 \\
88 \\
17\end{array}$ & $\begin{array}{r}3 \\
18 \\
19 \\
6 \\
23\end{array}$ \\
\hline \multicolumn{11}{|l|}{ Varved Diatomite } \\
\hline $\begin{array}{l}479-12-1,15-20 \\
479-22-7, \text { Bottom } \\
480-31-2,150-155\end{array}$ & $\begin{array}{r}98.2 \\
202.5 \\
148.8\end{array}$ & $\begin{array}{r}9434 \\
23,241 \\
23,178\end{array}$ & $\begin{array}{l}35 \\
48 \\
60\end{array}$ & $\begin{array}{r}7 \\
15 \\
17\end{array}$ & $\begin{array}{l}7 \\
4 \\
8\end{array}$ & $\begin{array}{l}37.1 \\
20.6 \\
25.9\end{array}$ & $\begin{array}{l}225 \\
369 \\
301\end{array}$ & $\begin{array}{l}2.29 \\
2.53 \\
2.39\end{array}$ & $\begin{array}{l}70 \\
72 \\
70\end{array}$ & $\begin{array}{l}15 \\
22 \\
20\end{array}$ \\
\hline
\end{tabular}

Note: Gas was extracted from canned samples and from head space in cans. On average, $60 \%$ of the gas comes from the head space. There is little or no compositional difference between the gas from the head space and that from the samples. Head space gases only were analyzed for Samples 447-20-2 and 479-22-7. 
anomalously high TOCs (about $3.6 \%$ ). Similarly enriched surface sediments also occur in Holes 475, 477, and 478 , according to shipboard data. These deep sea sediments are bioturbated, indicating that the water mass is not anoxic (Calvert, 1966). We suggest that upwelling results in the high biological productivity of surface waters in the gulf, and therefore large amounts of organic matter reach the bottom. Benthic activity (probably most of it bacterial) causes much of this organic matter (about $50 \%$ ) to be removed during early diagenesis within the top 10 meters of the sediment column in the oxidizing environments deeper than the oxygen minimum layer. Much less organic matter is removed in the reducing environments typical of the oxygen minimum layer. We believe that the gulf below the oxygen minimum is a marginally oxidizing environment, where there is more-than-usual preservation of organic matter.

The marine organic facies typical of the gulf margins are formed by (1) upwelling and attendant high biological productivity; (2) good preservation in oxygendepleted bottom waters; and (3) the aridity of the coast with its poor runoff and low rate of supply of terrestrial higher plant remains. The more terrestrial organic facies of the Guaymas Basin are formed by the dilution of the pelagic marine components by laterally supplied, terrestrial higher plant remains moving south down the axis of the gulf in turbidity currents supplied, probably by the Yaqui River. Some of the marine component also may move laterally into the basin by mass movements down the adjacent slopes. According to shipboard data, local fluctuations either in surface productivity (best developed in winter) or runoff (best developed in summer) give rise to a fluctuating supply of marine planktonic remains and terrigenous clay (with associated terrestrial plant remains). These fluctuations are preserved, where bottom waters are reducing, as the laminae seen at the varved diatomite sites. From the bulk composition of the varved diatomites, it is clear that the marine component predominates in the section.

As it has off the coast of Africa (Dow, 1977; Simoneit et al., 1978), the intrusion of sills has caused very localized thermal maturation within intruded sections. Most of the effects of this maturation are confined to within a few meters of each sill, although gas cooked off by sill intrusion may be more widespread. One section (Site 479) is mature because of hydrothermal alteration.

Regional variations in TAI are probably controlled by regional variations in heat flow. Excluding nearsurface TAI anomalies and the high TAIs caused by intrusions, TAIs are only 1 to $1+$ as deep as 450 meters in the Baja margin, where the heat flow averages $3.2 \mathrm{HFU}$ and reach no more than 2 - at depths of 250 meters on the mainland margin, where the heat flow is $2.4 \mathrm{HFU}$. All of the Guaymas Basin samples, where the heat flow averages $8.8 \mathrm{HFU}$ (range $=2.7-20 \mathrm{HFU}$ ), have TAIs of $1+$ or $2-$ (there are no lower values). These data suggest that, although the passive-margin samples may retain some of their potential for generating hydrocarbon, those from near the spreading center may lose much of their potential early in their history.
Gas is abundant in most sections, not only because of the enrichment in organic matter (which produces biogenic gas), but also because of the high heat flow and igneous intrusions (which produce thermogenic gas). It is the thermogenic gas that boosts the gas to twice that found in the organically enriched sediments of the California borderland-a nonthermal area.

Except in the Guaymas Basin, most of these sediments have very good potential for generating liquid hydrocarbons. Their organic matter is mainly amorphous, with a substantial marine component. Their paraffin composition is dominated by the marine contribution, and they are rich in extractable bitumensalso a good sign of liquid potential. Their alteration indices, except close to sills, are immature, which shows that their potential for liquid generation has not yet been reached. In the Guaymas Basin, the more terrestrial organic facies show that the section is more gas prone than the margins. The higher TAIs show that this sediment is closer to generating liquid hydrocarbons (some already will have been generated near the sills). By the time the sediments have moved away from the center of spreading, they may have been overcooked, losing their oil-generating potential. In the highly cooked, deeper parts of the section (Sites 477 and 478), the sediments contain a "black oily slick." This is reported to be a "condensate" adsorbed onto both finegrained minerals and the carbonaceous or asphaltic residues from extensive cooking. Sediments such as these have little potential for generating liquid.

Can we use this information to predict the hydrocarbon potential of geologically analogous sections elsewhere-for instance in the proto-Atlantic and similar basins? Certain conditions in ancient analogs probably were the same: high heat flow, hemipelagic sediments on the margins, and turbidites and sills in the basin floors. But the type and amount of organic matter depends greatly on the oceanic circulation pattern. The Gulf of California has a low-oxygen water mass (Calvert, 1964, 1966). But one of its modern counterparts, the Red Sea, is extremely well oxygenated, poorly productive, and does not have a rich marine organic facies. The answer to the question, then, requires rigorous paleoceanographic analysis of the early history of each ancient analog. If the water mass was not both highly productive and depleted in oxygen, we might expect the sediments to be similar to those in the margin of Japan, where TOCs are about $0.7 \%$, and $75 \%$ of the organic fraction is land-derived, gas-prone, woody, coaly, and herbaceous material (including spores and pollen) (Gilbert et al., 1980).

\section{SUMMARY}

The sediments of the Gulf of California are moderately rich in organic matter. Their organic facies are marine on the margins and mixed marine/terrestrial in the central Guaymas Basin. High productivity and low dissolved oxygen cause overall enrichment in labile marine organic matter. Terrestrial material is important where turbidity currents tap a terrestrial source (Yaqui River). Because of the regionally high heat flow, the 
deeper parts of some sections are approaching thermal maturity. This is especially true in the central basin, where seafloor spreading is active and parts of the section are extensively intruded or hydrothermally altered. Potentially, the margin sediments are very good sources for oil, and the basin sediments are potentially very good for gas and oil. But the basin sediments at some sites are extensively cooked and may have lost much of their potential for generating hydrocarbons. Ancient structural analogs of the Gulf of California will have the same types of sediment and similar hydrocarbon potential only if the paleocirculation was appropriate, with high productivity and low dissolved oxygen in the water column. Ancient equivalents of the central basin sediments may have lost much of their potential to generate hydrocarbons (except dry gas) because of extensive thermal alteration.

\section{ACKNOWLEDGMENTS}

Total organic carbon and gas were analyzed at Exxon Production Research Company by M. S. Bisotooni and H. M. Fry. D. Gilbert determined the types of organic matter and their thermal alteration indices. GeoChem Laboratories, Inc. (Houston) made the $\mathrm{C}_{15^{+}}$extracts and gas chromatograms. We thank J. B. Kulla, W. A. Young, J. P. Shannon, Jr., and B. R. T. Simoneit for reviewing this manuscript, and Exxon Production Research Company for permission to publish the results.

\section{REFERENCES}

Bernard, B. B., Brooks, J. M., and Sackett, W. M., 1976. Natural gas seepage in the Gulf of Mexico. Earth Planet. Sci. Lett., 31:48-54.

Calvert, S. E., 1964. Factors affecting distribution of laminated diatomaceous sediments in Gulf of California. In van Andel, Tj. H., and Shor, G. G. (Eds.), Marine Geology of the Gulf of California (Vol. 3): Tulsa (American Association of Petroleum Geologists), 311-330.

1966. Accumulation of diatomaceous silica in the sediments of the Gulf of California. Geol. Soc. Am. Bull., 77: 569-596.

Dow, W. G., 1977. Contact metamorphism of kerogen in sediments from Leg 41: Cape Verde Rise and Basin. In Lancelot, Y., Seibold, E., et al., Init. Repts. DSDP, 41: Washington (U.S. Govt. Printing Office), 821-824.

Einsele, G., et al., 1980. Intrusion of basaltic sills into highly porous sediments, and resulting hydrothermal activity. Nature, 283:441445.

Gilbert, D., Summerhayes, C. P., in press. Distribution of organic matter in sediments along the California continental margin. In Haq, B., and Yeats, R. S., et al. Init. Repts. DSDP, 63: Washington (U.S. Govt. Printing Office.

Gilbert, D., Summerhayes, C. P., and Johnson, D. L., 1980. Nature, origin, and petroleum source potential of organic matter from Deep Sea Drilling Project Sites 434, 435, 438, and 440 in the Japan Trench. In Scientific Party, Init. Repts. DSDP, 56, 57, Pt. 2: Washington (U.S. Govt. Printing Office), 1327-1330.

Masran, Th. C., and Pocock, S. A. J., 1979. Classification of plantderived particulate organic matter in sedimentary rocks. In Staplin, F. L. (Ed.), Kerogen-Visual and Chemical Relationships, a Symposium: Dallas (American Association of Stratigraphic Palynologists).

Simoneit, B. R. T., Brenner, S., Peters, K. E., et al., 1978. Thermal alteration of Cretaceous black shale by basaltic intrusions in the eastern Atlantic. Nature, 273:501-504.

Weeks, L. G., 1952. Factors of sedimentary basin development that control oil occurrence. Am. Assoc. Pet. Geol. Bull., 36: 20712124.

1958. Habitat of oil; a symposium. Am. Assoc. Pet. Geol. Spec. Pub., Tulsa, pp. 1-61. 